\title{
Do hubristic managers really matter on performance? Evidence from Nigerian firms
}

\author{
AYOBOLAWOLE ADEWALE OGUNDIPE * \\ University of Tasmania, Tasmania, Australia \\ ABIODUN RAFIAT AYENI-AGBAJE \\ OPEYEMI ROSELYN AKINDUTIRE \\ Ekiti State University, Nigeria
}

\begin{abstract}
We examine the implication of CEO hubris on the performance of Nigerian firms. Our study reveals that the determinants of hubristic managers like age, tenure, ownership, and political appointment adversely affect firm performance in the country. We propose that regulatory agencies of government should reduce; the age bracket of CEOs and the percentage of shares owned by CEOs. Besides, firms should not be allowed to make people with political connections or those who have once or presently in a political office a CEO because of its adverse effect on firm performance. Our study contributes to the extant literature on CEO hubris in at least two ways. First, we extend CEO hubris's implication on performance to Nigerian firms, since extant studies on firm performance in the country assume CEO rationality. Besides, existing studies on CEO hubris are from the eastern and western worlds. We take into consideration of the multidimensional nature of CEO hubris and firm performance than existing literature.
\end{abstract}

Keywords: Firm Performance, Hubristic Managers, Listed Firms

Abstrak: Kami memeriksa implikasi keangkuhan CEO pada kinerja perusahaan Nigeria. Studi kami mengungkapkan bahwa faktor penentu keangkuhan manajer seperti usia, masa kerja, kepemilikan, dan penunjukan politik mempengaruhi kinerja perusahaan di negara tersebut. Kami mengusulkan agar badan pengatur pemerintah harus mengurangi; kelompok usia CEO dan persentase saham yang dimiliki oleh CEO. Selain itu, perusahaan tidak boleh diizinkan untuk menjadikan orang yang memiliki koneksi politik atau mereka yang pernah atau sekarang menjabat sebagai CEO di kantor politik karena efeknya yang merugikan pada kinerja perusahaan. Studi kami berkontribusi pada literatur yang ada tentang keangkuhan CEO setidaknya dalam dua cara. Pertama, kami memperluas implikasi keangkuhan CEO pada kinerja untuk perusahaan Nigeria, karena studi yang ada tentang kinerja perusahaan di negara tersebut mengasumsikan rasionalitas CEO. Selain itu, studi yang ada tentang keangkuhan CEO berasal dari dunia timur dan barat. Kami mempertimbangkan sifat multidimensi dari keangkuhan CEO dan kinerja perusahaan daripada literatur yang $a d a$.

\footnotetext{
*Corresponding author: ayobolawole@gmail.com
} 
Kata Kunci: Kinerja Perusahaan, Hubristic Managers, Perusahaan Tercatat

\section{Introduction}

Traditional decision-making theories assume the concept of rationality; however, a fast-growing branch of business decisions-behavioral accounting and finance (BAF)argues the irrationality of a decision-maker, one of which is managerial hubris (Park, Kim, Chang, Lee \& Sung, 2018; Li \& Tang, 2010; Malmendier \& Tate, 2008; Hayward, Shepherd, \& Griffin, 2006; Malmendier \& Tate, 2005; Hayward \& Hambrick, 1997). Hubris, which was coined in psychology as excessive confidence about being correct (Michael \& Hussein, 2018; Fischhoff, Slovic, \& Lichtenstein, 1977), was introduced into economic research in 1986 by Roll, who hypothesized hubris on corporate takeovers. Subsequently, studies have linked the hubris hypothesis to; premiums paid by CEOs for large acquisitions (Hayward \& Hambrick, 1997), firm risk (Li \& Tang, 2010), stock performance in mergers and acquisition (Lo, 2019).

Among managerial behaviors identified in $\mathrm{BAF}$, hubris has been argued to influence firm performance. Notably, Malmendier and Tate (2008) argue that managerial hubris could lead to corporate collapse since hubristic managers are mostly engrossed in value-destroying activities. For instance, the corporate failures that characterized the earlier part of this century have been argued to result from hubristic managers' self-affirming features (Li \& Tang, 2010; Hayward \& Hambrick 1997).

To identify managerial hubris within a firm, BAF states the features of hubristic managers to include: exaggerated self-confidence, over-placement, inflated pride, overestimation (Park \& Chung, 2017; Olsson, 2014; Hayward \& Hambrick, 1997). The exaggerated self-confidence nature of hubristic managers results in overestimating the future performance, benefits and underestimate the cost of their enterprise above reality and thus, they pursue financial decisions that are unlikely to deliver the expected returns (Bikas, Jurevičienè, Dubinskas \& Novickyte, 2013; Rasheed, Sadaqat \& Chughtai, 2012). 
Due to the importance of managerial hubris to corporate existence, existing studies have explored the indicators of managerial hubris to include; the age of a Chief Executive Officer (CEO) (Noorfaiz \& Zuriawati, 2015; Huang, Tan \& Faff, 2013), CEO tenure, on the premise that hubris increases in managers over time (Berger, Ofek \& Yermack, 1997). Li and Tang (2010) argue complex markets, CEO duality, and intangibility of resources as influential factors on managerial hubris. Noorfaiz and Zuriawati (2015) claim that chief executives of firms with higher in-firm stock holding tend to be hubristic. Schrand and Zechman (2011), Ho and Chang (2009), and Puri and Robinson (2007) suggest that highly educated managers- CEOs with an educational background in firms' financial decisions-are most likely to be hubristic than those chief executive officers without an academic background in financial decision making. Orasanu and Connolly (1993) propose a considerable difference between the behavior of men and women CEOs. Male CEOs tend to be more hubristic than their female counterparts (Stinerock, Stem \& Solomen, 1991; Master, 1989; Estes \& Hosseini, 1988). Politically appointed executives make decisions that are in confirmation with the state's philosophy, which then reduces their level of cognitive bias as they are restrained from making self-interest decisions (Rasheed et al., 2012; Li \& Tang, 2010). Franco, Sanfilippo, and Seric (2018) claim that the business climate of the environment in which a firm operates in terms of institutional, policy, and regulatory environment influences managers' hubris level. On their part, Hayward and Hambrick (1997) note that past organizational success, media praises, and a strong perception of self-importance make business executives hubristic.

Despite the increasing studies (Noorfaiz \& Zuriawati, 2015; Huang, Tan \& Faff, 2013) on hubristic managers, there is a need to extend its implication on Nigerian firms' performance. First, Nigerian firms are characterized by overleveraging, earnings overstatement, asymmetric information, among others, which have been earlier stated as features of hubristic managers. For instance, the case of the Cadbury Nig. Plc., Afribank Plc., Lever Brothers Nig. Plc, in which their respective management overstated their earnings (Odunayo, 2014; Ajayi, 2006). Second, the extant studies on firm performance in the country assume CEO rationality, except for Michael \& Hussein 
(2018) that systematically reviewed the hubris hypothesis and management irrationality model. Since there is no accessible evidence on the effect of hubristic managers on Nigerian firms' performance, the only available studies (Kim \& Jang, 2020; Lo 2019; Park et al., 2018) were from the eastern and western world. Lastly, a recent study on managerial hubris and performance, such as Park et al. (2018), utilizes a single measure for firms' corporate performance; whereas, our study considers the multidimensional nature of firm performance. Based on the above, this paper examines the influence of hubristic managers on Nigerian firms' performance.

In summary, we contribute to the extant studies on managerial hubris and corporate performance. First, we consider the multidimensional nature of both managerial hubris and financial performance, which existing studies (Park et al., 2018). Second, our study extends the literature on managerial hubris to Nigeria, the biggest economy in Africa.

As this section introduces our study, the next section captures the literature review and the development of the hypothesis. Section three states the research methods. Section four discusses the result of this study, while the last section concludes.

\section{Literature Review and Development of Hypothesis}

The findings on managerial hubris and performance are mixed. In the US, Kim, and Jang (2020) disclose that overconfidence harms corporate profitability. However, a study conducted by Li, Hang, Shah, Akram, and Ozturk (2020) shows the cognitive characteristics of the CEO to boost the performance of Chinese SMEs. Lo (2019) finds that CEO hubris makes acquirers experience negative market reactions at the announcement and less negative long-term performance post-acquisition in the acquisition of low transparency firms. Among U.S. firms, Asimakopoulos and Yan (2019) indicate that expert power and prestige power have a positive and significant impact on firm performance, while formal power has a negative and significant on firm performance. In the Korean Stock Exchange, Park et al. (2018) disclose that CEO hubris has a negative and significant impact on firm performance. They note further that the CEO power aggravates the negative impact of CEO hubris on the financial performance, while board vigilance could mitigate such negative impact. This connotes that hubristic 
managers, coupled with excessive CEO power, could jeopardize corporate performance; however, a strong board could reduce managerial hubris's negative influence on firm performance. Vitanova (2018) find overconfidence to have a positive and significant influence on firm performance Souissi and Jarboui (2018) studied the effect of CEO emotional bias on the performance of Tunisian banks. The study disclosed that optimism and aversion to loss have a significant effect on banks' performance in Tunisia. Edwin and Benjamin (2017) disclosed that the high expectation of celebrity CEOs hams firms' performance. In the United States, Han, Lai, and Ho (n.d) studied that influence of CEO overconfidence on risk-taking and performance of insurance companies that are publicly traded property-liability with the use of a two-way fixed effects model and revealed, among other things that the impact of CEO overconfidence on the perform of the insurance companies is positive. Tang, $\mathrm{Li}$, and Yang (2015) revealed a positive relationship between executive hubris and firm innovation among firms in the U.S. and China.

Dhaouadi (2014) found out with the use of linear panel regression that top managers' age positively affects the corporate financial performance of firms in the United States. However, its effect is negative on the market valuation of the firms. Six, Normann, Stock, and Schiereck (2013) revealed that CEOs significantly impact firm performance and transactional policies than CFOs in German firms. Using stepwise regression, Gudmundsson and Lechner (2013) found out that overconfidence is highly and negatively influencing Icelandic entrepreneurial firms' firm survival. Lee, Miller, Velasquez, and Wann (2013) indicated a difference in the effect of behavioral biases of males and females on investment performance among students at U.S. University. With ANOVA, Lindorff, and Jonson (2013) revealed that no significant relationship exists between the CEO's business education and the financial performance of 183 organizations, which were in the ASX200 in May 2012. Jiang, Stone, and Sun (2011) disclose that CEO hubris has a negative relationship with firm profitability, resulting from overinvestment.

Koç (2011) found out that the relationship between leadership behaviors of managers located in the Ankara Ostim industrial zone in Turkey and employees' job 
satisfaction and performance of employees is significant. Bol (2011) found out that leniency bias and centrality bias positively and negatively affect performance improvement, respectively. Hmieleski and Baron (2009) revealed that the relation between entrepreneurs' optimism and a new venture's performance in the United States is negative. Lee, Yen, and Chen (2008) indicated that managers' tenure has a significant and positive impact on Taiwan's firm performance. Chatterjee and Hambrick (2007) disclosed a variation in the degree of CEOs narcissistic, with this variation having a significant impact on organizational performance. Lowe and Ziedonis (2006) discovered that entrepreneurial over-optimism is not influential on entrepreneurial firms' decisions at the University of California.

Based on the outcome of the above studies, we hypothesis that;

H1: Indicators of hubristic managers have a negative and significant impact on firm performance.

\section{Materials and methods}

This study adopts the Ex-post facto research design. We limit the population for this study to one hundred and seventy (170) listed firms on the Nigeria Stock Exchange (NSE) as of September 2018, out which an initial sample of 65 firms was selected for the years 2007-2017. We select the range because of the enactment of the Investments $\&$ Securities Act 2007, whereas 2017 ends the time series period because it provides the latest data observation in the listed firms' annual report. Besides, we exclude the remaining 105 firms as fifty-one (51) of them were listed after 2007 while the remaining fifty-four (54) had an invalid listing date on the NSE website, which may be due to temporary suspension from the market. Among the initial sample, we select fifty-five (55) firms-firms with updated data-for this study. The selected firms comprise twentyseven (27) highly regulated listed firms and twenty-eight (28) lowly regulated firms. We derive secondary data from; the firms' annual reports, the Central Bank of Nigeria statistical bulletin, African Financials, and Bloomberg. 


\subsection{Method of data analysis}

Our preliminary tests- Breusch Pagan Lagrange Multiplier (L.M.) Test and Hausman Test signify a fixed panel effect estimator as the suitable model estimator. We use Eviews 10 S.V. software.

The model for this study is specified in equation (1-4) below:

PERF $_{i t}=f\left(\right.$ MANGA $_{i t}$, MANGT $_{i t}$, MANGED $_{i t}$, MANGGEN $_{i t}$, MANGOWN $_{i t}$, POLAPT $_{i t}$, ENFDEV $_{i t}$, BUSCLINDX $_{i t}$, FIRMSZ $\left._{i t}, \mu\right)$

ROCE $_{i t}=\beta_{0}+\beta_{1}$ MANGA $_{i t}+\beta_{2}$ MANGT $_{i t}+\beta_{3}$ MANGED $_{i t}+\beta_{4}$ MANGGEN $_{i t}+\beta_{5}$ MANGOWN $_{i \mathrm{t}}+\beta_{6}$ POLAPT $_{i \mathrm{t}}+\beta_{7}$ ENFDEV $_{i \mathrm{t}}+\beta_{8}$ BUSCLINDX $_{i \mathrm{t}}+\beta_{9}$ FIRMSZ $_{i t}+\varepsilon_{t}$

EARNS $_{i t}=\beta_{0}+\beta_{1}$ MANGA $_{i t}+\beta_{2}$ MANGT $_{i t}+\beta_{3}$ MANGED $_{i t}+\beta_{4}$ MANGGEN $_{i t}+\beta_{5}$ MANGOWN $_{i t}+$ $\beta_{6}$ POLAPT $_{i \mathrm{t}}+\beta_{7}$ ENFDEV $_{i \mathrm{t}}+\beta_{8}$ BUSCLINDX $_{i \mathrm{t}}+\beta_{9}$ FIRMSZ $_{i t}+\varepsilon_{t}$

GROWTH $_{i t}=\beta_{0}+\beta_{1}$ MANGA $_{i t}+\beta_{2}$ MANGT $_{i t}+\beta_{3}$ MANGED $_{i t}+\beta_{4}$ MANGGEN $_{i t}+\beta_{5}$ MANG $\mathrm{OWN}_{i \mathrm{t}}+\beta_{6} \mathrm{POLAPT}_{i \mathrm{t}}+\beta_{7} \mathrm{ENFDEV}_{i \mathrm{t}}+\beta_{8} \mathrm{BUSCLINDX}_{i \mathrm{t}}+\beta_{9} \mathrm{FIRMSZ}_{i t}+\varepsilon_{t}$

PERFit represents firm performance, which we proxy with ROCEit-return on capital employed, EARNSit -earnings, and GROWTHit -growth. We proxy CEO hubris with MANGAit-managerial age, MANGTit -managerial tenure, MANGEDit managerial education, MANGGENit - managerial gender, MANGOWNit -managerial ownership, POLAPTit - political appointment, ENFDEVit -earnings forecast deviation, BUSCLINDXit - business climate index. We use firm size- FIRMSZit to control for firm characteristics. $\mu$ is the unobserved determinants of firm performance. The subscripts $i$ and t indicate firm and time period, respectively. et stands for stochastic error term, while $\beta 1-\beta 9$ is the shift parameters).

\subsection{Definition of operational variables}

In the measurement of the variables, we measure our explained variable-firm performance-with; earnings, which is the profit after tax of the firms, growth, which is the change in the firms' income, and return on capital employed, which is the percentage of profit after tax to capital employed. This paper measures explanatory variable-CEO hubris-with managerial age, which is the age of the CEO (Barno, 2017; Noorfaiz \& 
Zuriawati, 2015), a managerial tenure which is measured by the number of years the CEO stayed on the firm's helms of affairs (Irene \& Noor, 2015), managerial education is measured on a scale of 1-5, CEOs with only a senior secondary certificate are coded with 1, CEOs with Bachelor degree are coded with 2, Master's degree with 3, Ph.D. Degree with 4, while CEOs with professorship are coded with 5. Managerial gender, we scale female CEO with 0 while male CEO is measured with 1 (Barno, 2017); managerial ownership is the percentage of the shares of the firms owned by the CEO (Longjie \& Anfeng, 2017; Noorfaiz \& Zuriawati, 2015), a political appointment is the number of directors that is either holding or once held a political appointment, earnings forecast deviation is the difference between forecasted profit and actual profit (Kramer \& Liao, 2016; Ben \& Ben, 2016), while business climate index is the rate of institutional and regulatory policies in the industry (Longjie \& Anfeng, 2017) and firm size (Guillen, Erick \& Emre, 2014; Bikker \& Hu, 2002).

\section{Results and interpretations}

\subsection{Multicollinearity test}

The result in Table 4.1 shows that there is no strong linear relationship among the explanatory variables in the regression model because the variance inflation factors (VIF) test of these variables ranges from 1.030 to 1.331 , which is below the rule of thumb value of multicollinearity, which is 10 .

Table 4.1.

Variance Inflation Factors (VIF) Test

\begin{tabular}{|r|c|}
\hline \multicolumn{1}{|c|}{ Variable } & VIF \\
\hline MANGA $_{i t}$ & 1.320 \\
\hline MANGT $_{i t}$ & 1.331 \\
\hline MANGED $_{i t}$ & 1.098 \\
\hline MANGGEN $_{i \mathrm{t}}$ & 1.049 \\
\hline MANGOWN $_{i \mathrm{t}}$ & 1.119 \\
\hline POLAPT $_{i \mathrm{t}}$ & -1.064 \\
\hline ENFDEV $_{i \mathrm{t}}$ & 1.030 \\
\hline BUSCLINDX $_{i \mathrm{t}}$ & 1.083 \\
\hline FIRMSZ $_{i \mathrm{t}}$ & 1.029 \\
\hline
\end{tabular}

This table presents the variance inflation factors of the variables in this study.

Source: Authors' computation (2019) 


\subsection{Breusch pagan lagrange multiplier (LM) test}

This test determines the presence or otherwise of random effects in the regression models of this study. In this test, a low p-value counts against the null hypothesis that the pooled OLS model is adequate, in favor of the random effects alternative. A p-value above 5\% level of significance signifies the acceptance of the pooled OLS model, otherwise random effects. The results in Table 4.2 show the acceptance of random effects alternative because the p-value of the three (3) models are below 5\% level of significance. This signifies that the pooled OLS model is not suitable to estimate the models.

Table 4.2

Breusch-Pagan Test for Random Effects

\begin{tabular}{|c|c|c|c|}
\hline \multicolumn{4}{|c|}{ Lagrange Multiplier Tests for Random Effects } \\
\hline Null hypothese & No effects & & \\
\hline \multicolumn{4}{|c|}{ Alternative hypotheses: Two-sided (Breusch-Pagan) and one-sided } \\
\hline & \multicolumn{3}{|c|}{ Test Hypothesis } \\
\hline & Model 1 & Model 2 & Model 3 \\
\hline Breusch-Pagan & 154.463 & 322.156 & 441.083 \\
\hline Prob. & $(1.83445 \mathrm{e}-035)$ & $(4.91343 \mathrm{e}-072)$ & $(6.29132 \mathrm{e}-098)$ \\
\hline
\end{tabular}

This table presents the breusch-pagan test result for the random effects of models (2-4) in this study.

Source: Authors' computation (2019)

\subsection{Hausman test}

Table 4.3.

Hausman Test

\begin{tabular}{|l|c|c|c|}
\hline & \multicolumn{3}{|c|}{ Test Hypothesis } \\
\hline & Model 1 & Model 2 & Model 3 \\
\hline Hausman & 33.2246 & 34.094 & 130.789 \\
\hline Prob. & $(0.000122047)$ & $(8.59974 \mathrm{e}-005)$ & $(8.16111 \mathrm{e}-024)$ \\
\hline
\end{tabular}

This table presents the result of the Hausman Test for three models (2-4) in this study. Source: Authors' computation (2019)

This test determines the suitable estimator between random effect estimator and fixed effect estimator. A low p-value counts against the null hypothesis that the randomeffects model is consistent, in favor of the fixed-effects model. This test results suggest 
that the fixed effect estimator is the most appropriate estimator for the three (3) models of this study. This is because the results in Table 4.3 show that the p-value of the respective models is lesser than the 5\% level of significance. Based on this, this study focuses on fixed effects estimation results

\subsection{Model estimation results and discussion}

Table 4.4 shows that the constant parameter has a significant impact on performance; this implies that in a situation of no managerial hubris, the selected firm's performance is still favorable. The managerial age shows a significant impact of -0.0841 and 0.0686 ( $\mathrm{p}$-value $=0.0200,1.23 \mathrm{e}-09$ ), respectively, on proxies of performance-return on capital employed and growth. The negative effect of MANGAit on ROCEit implies that the higher the age of the chief executive officer, the lower the firm performance by $8 \%$. In contrast, the CEO age's positive effect on firm growth signifies that the CEO's age influences firm growth. In the case of earnings, the CEOs' age is not a determinant of earnings, since the p-value is higher than the $5 \%$ level of significance. This result is not in tandem with Dhaouadi (2014) findings that disclosed that top managers' age has a positive effect on the corporate financial performance of U.S. firms. However, its effect is negative on the market valuation of the firms. Besides, the negative (positive) effect of MANGAit on ROCEit (GROWTHit) signifies that top managers of the selected firm are more interested in the long-run performance of Nigerian firms rather than the short-run.

Managerial tenure has an inverse and significant effect of $-0.1175(0.0682)$ on firm growth. This implies that the more the CEO stays at the firm's helm of affairs, the lower the firm growth. However, MANGTit has no significant impact on the return on capital employed and the selected firms' earnings. This is not in agreement with Lee et al. (2008) that indicate managers' tenure to positively and significantly impact firm performance in Taiwan.

Managerial gender and managerial education are not influential on firm performance. The percentage of ownership controlled by the CEO, political appointment, and the deviation in the earnings forecasted by the CEOs have a significant impact of $-0.0464,-4.3592$, and 0.2894 ( $\mathrm{p}$-values $=0.0211,0.0082,0.0217$ ) respectively 
on return on capital employed; however, they do not show significant influence on earnings and growth. The business climate of the environment in which the firms operate has a positive and significant effect on firm performance- ROCEit and EARNSit by 0.0374 (p-value $=0.0003$ ) and 0.0087 (p-value $=0.0109)$, respectively. This depicts that a unit increase in the firm's business climate improves firm performancereturn of capital employed and earnings-by $3 \%$ and $0.8 \%$, respectively. The firm size is a robust determinant of corporate performance. It shows a significant impact on all the proxies of performance used in this study at a $1 \%$ level of significance.

Table 4.4.

Model estimation results: panel fixed effects estimator

\begin{tabular}{|c|c|c|c|c|}
\hline & & \multicolumn{3}{|c|}{ Explained Variables } \\
\hline Variables & $\begin{array}{l}\text { Expect } \\
\text { ed } \\
\text { Sign }\end{array}$ & $\mathrm{ROCE}_{i t}$ & EARNS $_{i t}$ & $\begin{array}{l}\text { GROWT } \\
\mathrm{H}_{i t}\end{array}$ \\
\hline Constant & & $\begin{array}{l}9.4760 * * \\
* \\
(0.0002)\end{array}$ & $\begin{array}{l}2.8432 * * \\
* \\
(0.0007)\end{array}$ & $\begin{array}{l}4.0468 * * \\
* \\
(3.01 \mathrm{e}- \\
07)\end{array}$ \\
\hline MANGA $_{i t}$ & + & $\begin{array}{l}-0.0841 * \\
* \\
(0.0200)\end{array}$ & $\begin{array}{l}-0.0015 \\
(0.8967)\end{array}$ & $\begin{array}{l}0.0686 * * \\
* \\
(1.23 \mathrm{e}- \\
09)\end{array}$ \\
\hline $\operatorname{MANGT}_{i t}$ & - & $\begin{array}{l}0.1506 \\
(0.4702)\end{array}$ & $\begin{array}{l}-0.0568 \\
(0.4095) \\
\end{array}$ & $\begin{array}{l}-0.1175^{*} \\
(0.0682)\end{array}$ \\
\hline MANGED $i t_{i t}$ & + & $\begin{array}{l}0.7329 \\
(0.3036)\end{array}$ & $\begin{array}{l}0.1069 \\
(0.6498)\end{array}$ & $\begin{array}{l}0.2688 \\
(0.2219)\end{array}$ \\
\hline $\begin{array}{l}\text { MANGGEN } \\
\text { it }\end{array}$ & - & $\begin{array}{l}0.0974 \\
(0.9447) \\
\end{array}$ & $\begin{array}{l}0.2188 \\
(0.6372) \\
\end{array}$ & $\begin{array}{l}-0.1924 \\
(0.6570) \\
\end{array}$ \\
\hline $\begin{array}{l}\text { MANGOW } \\
\mathrm{N}_{i \mathrm{t}}\end{array}$ & - & $\begin{array}{l}-0.0464 * \\
* \\
(0.0211)\end{array}$ & $\begin{array}{l}-0.0081 \\
(0.2202)\end{array}$ & $\begin{array}{l}0.0072 \\
(0.2386)\end{array}$ \\
\hline $\mathrm{POLAPT}_{i \mathrm{t}}$ & - & $\begin{array}{l}-4.3592 * \\
* * \\
(0.0082)\end{array}$ & $\begin{array}{l}0.5889 \\
(0.2783)\end{array}$ & $\begin{array}{l}-0.1353 \\
(0.7897)\end{array}$ \\
\hline $\mathrm{ENFDEV}_{i \mathrm{t}}$ & + & $\begin{array}{l}0.2894 * * \\
(0.0217) \\
\end{array}$ & $\begin{array}{l}0.0554 \\
(0.1828) \\
\end{array}$ & $\begin{array}{l}-0.0552 \\
(0.1558) \\
\end{array}$ \\
\hline $\begin{array}{l}\text { BUSCLIND } \\
\mathrm{X}_{i \mathrm{t}}\end{array}$ & + & $\begin{array}{l}0.0374 * * \\
* \\
(0.0003)\end{array}$ & $\begin{array}{l}0.0087 * * \\
(0.0109)\end{array}$ & $\begin{array}{l}-0.0001 \\
(0.9672)\end{array}$ \\
\hline FIRMSZ $_{i t}$ & + & $\begin{array}{l}0.4870 * * \\
* \\
(3.04 \mathrm{e}- \\
011)\end{array}$ & $\begin{array}{l}-0.0774 * \\
* * \\
(0.0007)\end{array}$ & $\begin{array}{l}0.4232 * * \\
* \\
(4.73 \mathrm{e}- \\
067)\end{array}$ \\
\hline
\end{tabular}


Table presents the fixed effect panel estimation results of models (2-4) with a sample of Nigerian listed firms from 2007 to 2017 . Notes: ***,**, and * indicate statistically significant at $1 \%, 5 \%$ and $10 \%$ significance level respectively. Also, we report p-values of the variables in ( ).

Source: Authors' computation (2019)

\section{Conclusion and recommendation}

Comparatively, low performing firms predominate most of the listed firms in Nigeria compared to other firms listed in other stock markets. Even though there are studies on firms' performance in the country, there is no accessible evidence on the effect of hubristic managers on listed firms' performance in the country. Based on this, we examined whether or not hubristic managers affect listed firms' performance in the country over the period 2007-2017. We utilize three different measures of firm performance and composite variables of hubristic managers. This study concludes that determinants of hubristic managers such as age, tenure, ownership, and political appointment adversely affect firm performance in the country. In contrast, business climate, size of the firm, and earnings deviation are mixed indicators of firm performance in Nigeria because they positively and negatively influence firm performance depending on the measure of performance under consideration. The findings concerning age, tenure, and ownership may be due to old, long-tenured, and high percentages in the ownership structure of most CEOs in Nigeria. For policy implication, we propose that regulatory agencies in charge of listed firms reduce the age bracket of CEOs in the country. Besides, there should be a reduction in the percentage of in-firm shares that CEOs can own in the country. Firms should not be allowed to make people with political connections their CEOs because of its adverse effect on firm performance. We recommend that future BAF studies examine the implication of hubris on public governance, foreign investment, genetics, and corporate philanthropy.

We contribute to the extant literature on CEO hubris in at least two ways. First, we extend CEO hubris's implication on performance to Nigerian firms, since extant studies on firm performance in the country assume CEO rationality. Besides, existing studies on CEO hubris are from the eastern and western worlds. We take into consideration of 
the multidimensional nature of CEO hubris and firm performance than existing literature.

Acknowledgments: We appreciate the comments, suggestions, and contributions of the editor(s) and anonymous referees who had gone far in improving the quality of this research work. We are liable for the errors.

\section{References}

Ajayi, B., (2006). Cadbury: Nigeria’s Enron, Nigeriaworld.com.

Asimakopoulos, S. \& Yan, H. (2019). The role of formal and informal CEO power on firm performance. (October).

Barno, L.J. (2017). Impact of managers' characteristics on capital structure among firms listed in Nairobi Securities Exchange, Kenya. International Journal of Economics, Commerce and Management, 5(7), 487-503.

Ben, A. R. \& Ben, J. L. (2016). Managerial overconfidence and debt decisions. Journal of Modern Accounting and Auditing, 12(4), 225-241. doi: 10.17265/15486583/2016.04.004

Berger, P. G., Ofek, E., \& Yermack, D. L. (1997). Managerial entrenchment and capital structure decisions. The Journal of Finance, 52(4), 1411-1438.

Bikas, E., Jurevičienė, D., Dubinskas, P., \& Novickyte, L. (2013). Behavioral finance: The emergence and development trends. Procedia-social and behavioral sciences, 82, 870876.

Bikker, J. A., \& Hu, H. (2002). Cyclical patterns in profits, provisioning, and lending of banks procyclicality of the new Basel capital requirements. BNL Quarterly Review, 221, 143 175.

Bol, J. C. (2011). The determinants and performance effects of managers' performance evaluation biases. Accounting Review, 86(5), 1549-1575. https://doi.org/10.2308/accr$\underline{10099}$

Chatterjee, A. \& Hambrick, D. C. (2007). It's all about me: Narcissistic CEOs and their effects on company strategy and performance. Administrative Science Quarterly, 52: 351-386.

Dhaouadi, Karima. (2014). The influence of top management team traits on corporate financial performance in the U.S. Canadian Journal of Administrative Sciences / Revue Canadienne des Sciences de l'Administration. 31(3). https://doi.org/10.1002/cjas.1288 
Edwin, W \& Benjamin, M. (2017). Celebrity chief executive officers influence on firm performance: A review of theory and evidence. International Journal of Economics and Management Sciences 6(5), 1-14. DOI: 10.4172/2162-6359.1000460

Estes, R. \& Hosseini, J. (1998). The gender gap on Wall Street: an empirical analysis of confidence in investment decision making. The Journal of psychology, 1\&2(6), 577590.

Fischhoff, B., Slovic, P. \& Lichtenstein, S. (1977). Knowing with certainty: The appropriateness of extreme confidence. Journal of Experimental Psychology: Human Perception and Performance, 3(4), 552-564.

Franco, C., Sanfilippo, M. \& Seric, A. (2018). Investors' characteristics and the business climate as drivers of backward linkages in Vietnam. Journal of Policy Modeling. https://doi.org/10.1016/j.jpolmod.2018.09.002

Gudmundsson, S. V., \& Lechner, C. (2013). Cognitive biases, organization, and entrepreneurial firm survival. European Management Journal, 31(3), 278-294. https://doi.org/10.1016/j.emj.2013.01.001

Guillen, J., Erick, W. R, \& Emre, O. (2014). Relative power and efficiency as a main determinant of banks' profitability in Latin America. Borsa Istanbul Review, 14, 1-7.

Koç, H (2011). The impact of managers' leadership behaviors on job satisfaction and performance of employees. African Journal of Business Management, 5(30). https://doi.org/10.5897/ajbm10.1229

Han, S., Lai, G. C., \& Ho, C. (n.d). CEO overconfidence or private information? Evidence from U.S. Property-Liability Insurance Companies.

Hayward, M. L. A., \& Hambrick, D. C. (1997). Explaining the premiums paid in large acquisitions: Evidence of CEO hubris. Administrative Science Quarterly, 42, 103-127.

Hayward, M. L. A., Shepherd, D. A., \& Griffin, D. (2006). A hubris theory of entrepreneurship. Management Science, 52(2), 160-172.

Hmieleski, K. M., \& Baron, R. A. (2009). Entrepreneurs' optimism and new venture performance: A social cognitive perspective. Academy of Management Journal, 52(3), $473-488$.

Ho, C.R., \& Chang, Y. (2009). CEO overconfidence and corporate financial distress. SSRN working paper, No. 1659440.

Huang, R., Tan, K. J. K., \& Faff, R. (2013). CEO overconfidence and corporate debt maturity. Available at SSRN 2311530.

Irene, W. K. T. \& Noor, A. B. A. (2015). Managerial overconfidence and debt decision: Evidence from Malaysia. Journal of Advanced and Applied Sciences, 3(4), 125-135. 
Jiang, F., Stone, G. R., Sun, J., \& Zhang, M. (2011). Managerial hubris, firm expansion, and firm performance: Evidence from China. Social Science Journal, 48(3), 489-499. https://doi.org/10.1016/j.soscij.2011.05.007

Kim, H. S., \& Jang, S. C. (2020). CEO overconfidence and firm performance: The moderating effect of restaurant franchising. Cornell Hospitality Quarterly. https://doi.org/10.1177/1938965519899926

Kramer, L. A. \& Liao, C. M. (2016). The spillover effects of management overconfidence on analyst forecasts. Journal of Behavioral and Experimental Finance, 12, 79-92.

Lee, J. S., Yen, P. H., \& Chen, Y. J. (2008). Longer tenure, greater seniority, or both? Evidence from open-end equity mutual fund managers in Taiwan. Asian Academy of Management Journal of Accounting and Finance, 4(2), 1-20.

Lee, K., Miller, S., Velasquez, N., \& Wann, C. (2013). The effect of investor bias and gender on portfolio performance and risk. The International Journal of Business and Finance Research, 7(1), 1-16.

Li, H., Hang, Y., Shah, S. G. M., Akram, A., \& Ozturk, I. (2020). Demonstrating the Impact of Cognitive CEO on Firms' Performance and CSR Activity. Frontiers in Psychology, 11(February), 1-8. https://doi.org/10.3389/fpsyg.2020.00278

Li, J. \& Tang, Y. (2010). CEO hubris and firm risk-taking in China: the moderating role of managerial discretion. Academy of Management Journal, 53(1), 45-68.

Lindorff, M. \& Jonson, E. P. (2013). CEO business education and firm financial performance: a case for humility rather than hubris. Education + Training, 55(4/5), 461-477, https:// doi.org/10.1108/00400911311326072

Lo, Y. L. (2019). Acquirer Hubris and Stock Performance in Mergers and Acquisitions Market. The Journal of International Management Studies, 14(1), 82-91.

Longjie, X. \& Anfeng, Z. (2017). The impact of managers overconfidence on corporate investment. International Journal of Social Science and Humanity, 7(2), 109-114.

Lowe, R. A., \& Ziedonis, A. A. (2006). Over-optimism and the performance of entrepreneurial firms. Management Science, 52: 173-186

Malmendier, U., \& Tate, G. (2005). CEO overconfidence and corporate investment. The Journal of Finance, 60(6), 2661-2700.

Malmendier, U., \& Tate, G. (2008). Who makes acquisitions? CEO overconfidence and the market's reaction. Journal of Financial Economics, 89(1), 20-43.

Masters, R. (1989). Study examining investor risk-taking propensities. Journal of financing planning, 2(3), 151-155. 
Michael, C. I., \& Hussein, M. (2018). Hubris Hypothesis and Model of Managerial Irrationality. 3(2), 53-73.

Nkwagu, C. L., Uguru, L. C., \& Nkwede, F. E. (2016). Implications of international public sector accounting standards on financial accountability in the Nigerian public sector: A study of southeastern states. IOSR Journal of Business and Management (IOSR-JBM), 18(7), 105-118. https://doi.org/10.9790/487X-180704105118

Noorfaiz, P \& Zuriawati, Z. (2015). Managerial overconfidence and debt maturity structure. Review of Contemporary Business Research, 4(1), 32-39. doi: 10.15640/rcbr.v4n1a4

Odunayo, B.A (2014), "Fraudulent financial reporting: The Nigerian experience," proceedings of the Clute Institute international conference in San Antonio Texas, USA, 2007, pp. 18-30.

Olsson, H. (2014). Measuring overconfidence: Methodological problems and statistical artifacts. Journal of Business Research, 67, 1766-1770.

Orasanu, J. \& Connolly, T. (1993). The reinvention of decision making. In G Klein, J Orasanu, R Calderwood \& CE Zsambok (Eds.), Decision making in action: Models and methods (3-20). Norwood, NJ: Ablex.

Park, J. \& Chung, C.Y. (2017). CEO overconfidence, leadership ethics, and institutional investors. Sustainability, 9(14), 1-28. doi:10.3390/su9010014

Park, J. H., Kim, C., Chang, Y. K., Lee, D. H., \& Sung, Y. D. (2018). CEO hubris and firm performance: Exploring the moderating roles of CEO power and board vigilance. Journal of Business Ethics, 147(4), 919-933. https://doi.org/10.1007/s10551-015$\underline{2997-2}$

Puri, M., \& Robinson, D. T. (2007). Optimism and economic choice. Journal of Financial Economics, 86(1), 71-99.

Rasheed, R., Sadaqat, S. \& Chughtai, S. (2012). Managerial overconfidence and discretion: Do managerial hubris affect the dividend policy in Pakistan?. IOSR Journal of Business and Management, 6(4), 50-62.

Roll, R. (1986). The hubris hypothesis of corporate takeovers. Journal of Business, 2(59), 197216.

Schrand, C. M. \& Zechman, S. L. (2011). Executive overconfidence and the slippery slope to financial misreporting. Journal of Accounting and Economics, 53, 311-329.

Six, B., Normann, M., Stock, R. M., \& Schiereck, D. (2013). Strategic leaders' impact on corporate policies and firm performance: Insights from CEOs and CFOs of large listed firms in Germany. Schmalenbach Business Review, 65/2, 82-111.

Souissi, Y., \& Jarboui, A. (2018). Does CEO emotional bias affect performance? Cogent Economics and Finance, 6(1). https://doi.org/10.1080/23322039.2018.1453452 
Stinerock, R., Stem, B. \& Solomen, M. (1991). Sex and money: Gender differences in the use of surrogate consumers for financial decision making, Journal of Professional Servies Marketing, 7(2), 167-182.

Tang, Y., Li, J., \& Yang, H. (2015). What I see, what I do: how executive hubris affects firm innovation. Journal of Management, 41(6), 1698-1723. https://doi.org/10.1177/0149206312441211

Vitanova, I. (2019). Nurturing overconfidence: The relationship between leader power, overconfidence, and firm performance. The Leadership Quarterly, (June 2018), 101342. https://doi.org/10.1016/j.leaqua.2019.101342 
The Indonesian Journal of Accounting Research - Sept, Vol. 23 , No.3 , 2020

intentionally blank 